\title{
EquiLIBRIUM
}

Quarterly Journal of Economics and Economic Policy

2015 VOLUME 10 ISSUE 2, June

p-ISSN 1689-765X, e-ISSN 2353-3293

www.economic-policy.pl

Świadek, A. (2015). The Economic Cycle and the Innovation Activity of the Polish Industry System. Equilibrium. Quarterly Journal of Economics and Economic Policy, 10(2), pp. 75-92, DOI: http://dx.doi.org/10.12775/ EQUIL.2015.014

Arkadiusz Świadek*

University of Zielona Góra, Poland

\section{The Economic Cycle and the Innovation Activity of the Polish Industry System}

JEL Classification: $L 52 ; P 51 ; O 12 ; O 25 ; O 31 ; O 38 ; O 47$

Keywords: innovation; economic cycle; industrial system; probability

\begin{abstract}
Industrial structures in the "catching up" type of countries usually are not too competitive in nature, and they mainly differ in the low share of hightechnology products in the international trade. The aim of the conducted studies was an attempt to search for directions, as well as the power of impact of different phases of the business cycle on the innovation activity of the Polish industrial system. Consequently, this was to allow to determine the boundary conditions for the national network of innovations and its model structure, which would take into account the specificity of Poland. The methodical part of the paper was based on the theory of probability (probit modelling). Based on the analysis performed based on 5209 industrial companies (questionnaire survey) it was stated that in the prosperity phase the implementation of the innovation activity is significantly higher than in other phases of the business cycle. On the other hand, during recession and stagnation, the innovation activity is a less common phenomenon, but is not completely abandoned. Research results did not confirm the occurrence of the counter-cyclical approach to the conducted innovation activity in the national industrial system. The economic situation is thus an important factor, which influences the decision whether to undertake, activate or, in some cases, limit the inno-
\end{abstract} Toruń

(C) Copyright Institute of Economic Research \& Polish Economic Society Branch in

Date of submission: December 18, 2014; date of acceptance: May 5, 2015

* Contact: e-mail a.swiadek@wez.uz.zgora.pl, University of Zielona Góra, ul. Podgórna 50 budynek A-0, 65-246 Zielona Góra, Poland 
vation activity in companies. Therefore, there is a need to take into account the existing market conditions in the programming of the innovation policy within the impact on the phenomenon of the innovation processes in Poland.

\section{Introduction}

In Europe there is a the systematic, but slow process of recovery from the economic crisis, which is confirmed by various economic indicators in individual member states of the European Union. This allows for an optimistic look into the near future. This does not change the fact that the observed state of slowdown can still take a long time. Entities operating in this cycle phase are under peer pressure and often decide on strategies of cost reduction in a short period of time, without devoting much time to the exploration of factors responsible for the creation of the long-term competitive advantage, understood as the innovation strategy (Barett et al., 2009). In a short period of time, the lack or limitation of financing such activity of the companies may result in the stretched or reduced budgets for creating and implementing new technologies, which will ultimately lead to delays in developing new products and processes, limitation of their quality, and even stopping the part of the innovation projects.

The problem of the influence of the conjunctural cycle on the innovation activity of companies is not a new phenomenon, but it still remains in the area of interest of science, which is confirmed by the publications constantly appearing in this field on both the national and foreign market (Dominiak \& Churski, 2012, pp.54-77; Etzkowitz \& Leydesdorff, 2000, pp. 109123; Archibugi et al., 2013, pp. 1247-1260; D’Estea et al., 2012, pp. 482488). At the company level, literature in economics shows the diverse influence of the economic slowdown on the dynamics of innovation expenditures. There is a dispute broadly described in this scope. Traditionally, investments into new technologies should be treated as the counter-cyclical measure for companies operating on the market, because limitations taking place in the downturn influence the level of their profitability, which generates the imperative to seek paths to obtain higher productivity. Thus, according to the concept of "creative destruction" by J. Schumpeter, the crisis creates new perspectives for economic entities (Schumpeter, 1939). As a result, many of them should aim to reorganise the structures and improve the quality of own innovation activity. A manifestation of this approach may be the R\&D sphere personnel, which during the crisis is subject to the natural phenomenon of "work hoarding". That is, the most qualified employees are "stored" in the company thanks to the lower qualification personnel (Soete, 2009). This generates new potential possibilities to develop 
the organisation. In turn, the lost profits resulting from the limited labour demand of the directly manufacturing employees should be, during recession, a contribution for the new companies for new investments in the area of technology (Stiglitz, 1993; Aghion, \& Saint-Paul, 1998, pp. 279-303; Canton \& Uhlig, 1999, pp. 239-266). As it is known that the chances of bankruptcy of the companies, which do not implement the reorganisation programs, are higher in the recession phase (Aghion \& Saint-Paul, 1998, pp. 279-303).

Despite many logical and common sense arguments that the innovation activity of companies should by counter-cyclical in nature, in literature there often exists in parallel a notion that managers of companies do not treat the innovation activity differently than its remaining functions. This means that this activity should have the cyclic nature. In the modern economy, generation and implementation of new technologies, mostly the fundamental ones, is delayed during the recession, and companies are waiting for the next wave of recovery (Shleiffer, 1986, pp. 1163-1190; Francois \& Lloyd-Ellis, 2003, pp. 530-550). In this situation there is no scientific consensus in the area of veracity of the Gerhard Mensch's ,acceleration of innovation" hypothesis of 1975, assuming that innovations, especially the radical ones, are more often implemented in the recession phase as an attempt to search new opportunities for companies willing to survive on the shrinking market (Clark et al., 1981, pp. 308-322).

The economic situation is an important factor, which can often influence the decisions about taking or abandoning the innovation activity by industrial companies, both in Poland and in the more developed countries. The Polish industrial system due to its underdeveloped, but improving, character more often depends on the changes taking place in its closer and further environment, and therefore in more developed countries. Studies conducted in the SME manufacturing sector in Spain in 2013 confirm and at the same time generate equivocal conclusions in the analysed sector, and they come down to the following theses (Madrid-Guijarro et al., 2013, pp. 578-601): (1) innovation of small and medium industrial companies decreases during the economic crisis, (2) types of the implemented innovations in the Spanish SME change in different economic conditions, and what is extremely interesting, (3) innovation has a beneficial influence on the results of companies both during the economic development and the recession. The obtained results of studies show that the innovation strategies in the SME sector, despite different phases of the economic cycle, have a significant impact on the efficiency of its functioning and these conditions should be included in the planned and implemented innovation policies. This provides 
the rationale to conduct analyses in terms of the intensity of involvement in a variety of innovation activity due to changes of the business cycle phases.

Therefore, it can be concluded that the discussion in the studied area was not completed, and the economic impact on the technological changes in the companies seems to be a phenomenon more heterogeneous in nature than it has been previously thought. The analyses presented in the work aim to, even a little, enrich the current state of knowledge in this area, especially in an attempt to explain the conditions of functioning of the economic systems in the "catching up" type of countries.

The essence of the innovation systems are the relations taking place between the individual participants of the market forming the network of links. However, this does not mean that the innovation systems operate in a vacuum, because they are embedded in specific economic conditions. Research conducted by Joint Research Centre (JRC) in the area of assessing the influence of the market conditions on the innovation activity of the economy became the reason to undertake an attempt to assess these phenomena in Poland (JRC, 2010). The results of the analyses conducted there still confirm the ambiguity of this phenomenon and its impact on the innovation activity. Thus, the question remains unresolved: is the economic boom or recession the factor stimulating the companies to adept proinnovation attitudes?

The primary objective of the study was, therefore, the attempt to search for directions, as well as the power of impact of the economic situation on the innovation activity of companies within the Polish industrial system. Consequently, this was to allow the determination of boundary conditions for the national network of innovation and its model structure, which would take into account the specificity of Poland. The effects of original research presented in this article are only a part of the conclusions, which were obtained as a result of the conducted multi-threaded analyses in the country over the last six years.

The exemplification layer of the paper was based on the study in detail exploring the Polish industry. The studies were conducted based on the questionnaire conducted on a group of 5209 industrial enterprises (the number of sent and correctly completed questionnaires), including 4615 enterprises with the exclusive national capital, 281 - with the foreign capital and 313 enterprises with the mixed ownership structure. Due to the lack of funding of the conducted studies they were spread in time and lasted six years (2007-2012). The simultaneously created database of companies is constantly updated, because the works on the attempt to repeat the studies in next provinces are underway. The basic path of data collection was the procedure connecting the initial telephone conversation with the submis- 
sion of the questionnaire form by mail. The complementary forms included the telephone interview or acquiring the filled in questionnaire by e-mail, or fax. The incorrectly filled questionnaire, depending on the character of the mistake, essentially disqualified it from the opportunity to participate in subsequent stages of the study. The structure of the studied companies approximately corresponded to the data presented by the Central Statistical Office. However, unlike the studies conducted in it, the micro-enterprises sector was also taken into account, which is an incidental phenomenon in the scale of our country, trying to present holistically the way of functioning of the national industrial system in Poland.

All analyses were static and were conducted in the three-year arrangement, referring to the methodological standards over the R\&D sphere and innovations conducted in the OECD countries. Because of this, there was a possibility to conduct the analysis for a longer period of time, without a significant impact on the final results of the study..

\section{Methodology of the Research}

The methodological part of analyses was based on the theory of probability. The group of eighteen variables included:

a) the occurrence of expenditures on the innovation activity in the companies, but in connection to their structure, that is the R\&D sphere, investments in new machines and technical equipment, as well as buildings, constructions, lands and investments in new computer programs,

$$
\mathrm{Y}_{1 \mathrm{i}}=\left\{\begin{array}{c}
1, \text { if expanditures exist } \\
0, \text { if expanditures doesn't exist }
\end{array}\right.
$$

b) implementation of new processes and products, taking into account the specific solutions in this regard, and thus new products and new technological processes,

$$
\mathrm{Y}_{1 \mathrm{i}}=\left\{\begin{array}{c}
1, \text { if implemantaion exists } \\
0, \text { if implemantation doesn't exist }
\end{array}\right.
$$

c) cooperation in the area of the innovation activity in terms of the subject, that is with suppliers, competitors and recipients, as well as universities, JBR and foreign research institutes. 


$$
Y_{1 i}=\left\{\begin{array}{c}
1, \text { if cooperation exists } \\
0, \text { if cooperation doesn't exist }
\end{array}\right.
$$

Independent variables which were used in the study are the three economic phases: revival, stagnation and recession, which were identified by entrepreneurs based on information about the incomes earned in the last three years. If the incomes in the company increased in the studied period, it was assumed that it is in the revival phase. If the incomes decreased - in the recession phase, and when they did not change: in the stagnation phase.

$$
\begin{aligned}
& \mathrm{X}_{1 \mathrm{i}}=\left\{\begin{array}{c}
1, \text { if enterprise declares economic prosperity } \\
0, \text { if enterprise declares doesn't declare economic prosperity }
\end{array}\right. \\
& \mathrm{X}_{2 \mathrm{i}}=\left\{\begin{array}{r}
1, \text { if enterprise declares economic recession } \\
0, \text { if enterprise declares doesn't declare economic recession }
\end{array}\right. \\
& \mathrm{X}_{3 \mathrm{i}}=\left\{\begin{array}{c}
1, \text { if enterprise declares economic stagnation } \\
0, \text { if enterprise declares doesn't declare economic stagnation }
\end{array}\right.
\end{aligned}
$$

Based on this selection of independent and dependent variables there was an attempt to define the interactions occurring between the prosperity phase, in which the company can be found, and the actual innovation activity (financial, implementation and innovation cooperation). However, taking into account the fact that the subject of the study covered the industrial system in Poland and not the single company, then obtained conclusions with the induction method and thanks to the applied statistical tools apply to the whole group of entities. While the probability values approximated in the analytical part of the article are crucial to determine the potential effectiveness of the instruments of the innovations policy - its directions and force of impact.

The adopted independent variables are a set of reference planes, which illustrate the innovation activity of industrial companies, adopted on the basis of the methodology commonly used for the OECD countries since the 80 s of the last century (OECD, 2005). A set of features describing the innovation activity of industrial companies at the input (expenditures) and the output (implementation and cooperation) was distinguished. At the same time, to date, the synthetic measure describing the innovation activity on the industry level has not been developed, although the attempts of its system recognition can be found in the literature (KE, 2013). However, they 
often encounter greater or lesser criticism due to the heterogeneous nature of this activity, difficult to be brought to a common denominator, and the applied measures have specific and, at the same time, limited use.

The statistical verification of models was conducted basing on the Wald's Chi-square statistics, while the verification of parameter relevance with the $t$-student test using the asymptotic standard errors of assessment. We adopted the confidence limits at the level of $+/-95 \%$ - for the model and its parameters. Due to the number of estimated models it was decided to present only those which meet the condition of the statistical significance - both of the whole model, and its parameter (of the considered factor).

It is also worth noting that both the dependent and independent variables had the binary character. On one hand, this is connected with the fact of necessity to collect a significant number of the properly filled questionnaires - the system study, and on the other, the maximal simplification of questions included in it. This does not change the fact that the nature of the questions asked was consistent with the international methodological standards and the practice adopted in this field. For this reason, it was only decided to form the univariate models - the lack of continuous variables on the input allowing for more precise conclusions, however, stressing the directions of the statistically significant connections found between the variables adopted for the study. This proved to be sufficient for the evaluation of the studied phenomena. Based on the theory of probability, the chances of occurring of particular areas of the innovation activity can be estimated, provided that there exist selected boundary conditions, and they plan and strengthen the effects of impact of the innovation policy instruments.

In case when the dependent variable gets dichotomous values, there is no chance to use the multiple regression, commonly applied in the quantitative phenomena. An alternative for such a situation is the use of the probit regression. Its advantage, undoubtedly, is the fact that the analysis and interpretation of the results is similar to the classical regression method. Methods for variable selections, as well as testing the hypotheses, thus have a similar pattern. However, there are differences which may include, among others: more intricate and time-consuming calculations, as well as calculating values and creating residue charts, which often do not provide anything new to the model (Stanisz, 2007).

In case of a model in which the dependent variable takes the value of 0 or 1 , the expected value of the dependent value adopted for the model may be interpreted as the conditional probability of the execution of the given event, taking into account the determined values of the independent variables. The applied modelling of this probit type allowed to evaluate the 
chance of existence of diverse behaviours within the scope of the innovation activity depending on the previously adopted boundary conditions.

Conducting all calculations has been done with the use of the Statistica software. Due to the aesthetics of the presentation of the results of the conducted studies, it was decided to present only the basic properties of the econometric models, which met the assessment criteria of the significance of the parameters and models, at the same time resigning from the developed form of presentation, however, taking into account the calculated standard errors, assessment statistics of the model significance as a whole and the probability of occurrence of the phenomena.

All variables adopted for the study, therefore, both the dependent and independent variables are binary in nature, that is they reach the values of 1 or 0 , and therefore the interpretation of the study results has been conducted based on the structural form of the model and achieved probability values. The positive sign of the parameter means that the probability of the event of the innovative nature is significantly higher in the distinguished group of industrial companies in relation to the rest of the group. The probit type of modelling is a very effective research tool, however, mostly in case of large, but at the same time statistical research samples, where the dependent variable takes the qualitative form.

As it has been already mentioned in the introduction, the study was conducted based on the sample of 5209 industrial companies in Poland. The structure of the studied companies from the point of view of the size and technology is presented by the table below.

Table 1. The structure of industrial enterprises by firm size and technology level (in percent)

\begin{tabular}{|l|l|c|l|c|}
\hline No & Firm size & Poland & Technology level & Poland \\
\hline 1 & Micro $(<10)$ & 36,3 & Low & 52,2 \\
\hline 2 & Small $(<50)$ & 36,3 & Medium low & 29,6 \\
\hline 3 & Medium $(<250)$ & 21,5 & Medium high & 13,2 \\
\hline 4 & Large $(>249)$ & 5,9 & High & 5,0 \\
\hline
\end{tabular}

Source: own study based on questionnaire research evidence.

The conducted analysed were statistical in nature, which is important from the viewpoint of maintaining the comparability of data and they were conducted in a three-year arrangement with methodological standards of research over the innovations conducted in the OECD countries (OECD, 2005). 


\section{The Economic Prosperity and the Innovation Activity of the Industrial Companies}

Subjecting a group of companies declaring boom to the probit modeling, interesting and homonymous study results were obtained. For all analysed areas of innovation, statistically important parameters with the positive sign were obtained, without exception. This means that industrial companies are statistically more often prone to undertaking any of the considered innovation activities in the revival phase than in other phases of the economy cycle (cf. Archibugi et al., 2013, pp. 1247-1260). These positive dependencies can be observed both for the financial expenditures incurred for research and development, implementation of new technological processes, and the innovation cooperation, and this process is referred to in the literature as "creative accumulation" (Pavitt et al., 1999, Malerba \& Orsenigo, 1995, pp. 47-65). Thus, the obtained results of studies confirm the meaning of supporting this group of entities with different instruments of the innovation policy, either on the national or regional level. Moreover, already at this stage of solutions, in the Polish industrial system doubts are caused by the counter-cyclical hypothesis of Gerhard Mensch - "acceleration of innovation".

Considering in detail the values of probabilities, however, we can observe several other interesting probabilities. Firstly, there is a wide diversity between the mathematical value of chances in the areas of financing and implementation, and the innovation cooperation. Companies in the boom period, although more often than other entities, finance and implement new solutions, still they are less often interested in entering into cooperation relations, mostly horizontal (Jasiński, 2014; CSO, 2012). High probability values are obtained for the investment into fixed assets $(0,83)$, including the purchase of machines and devices $(0,75)$ and computer software $(0,59)$, implementation of new products $(0,59)$ and technological processes $(0,81)$, with emphasis on the new methods of their production $(0,55)$.

In the area of the innovation cooperation, entities are more often interested in the vertical connections - with suppliers $(0,31)$ and recipients $(0,25)$, whereas the horizontal ones are very rare, regardless of the considered cooperation entity (chances close to zero). 
Table 2. The parameter value for the independent variable „economic prosperity”, in the probit models describing the system of industrial innovation in Poland

\begin{tabular}{|l|c|c|c|c|c|c|c|}
\hline \multicolumn{1}{|c|}{ Innovation feature } & Coef & $\begin{array}{c}\text { Std. } \\
\text { error }\end{array}$ & $\boldsymbol{t}$-test & $\mathbf{C h i}^{2}$ & $\mathbf{P}>|\mathbf{z}|$ & $\mathbf{p}_{\mathbf{1}}$ & $\mathbf{p}_{\mathbf{2}}$ \\
\hline R\&D expenditure & $\mathbf{+ 0 , 5 7 4}$ & 0,037 & 15,66 & 249,86 & 0,00 & $\mathbf{0 , 4 5}$ & 0,24 \\
\hline $\begin{array}{l}\text { Investment in new fixed assets } \\
\text { (including): }\end{array}$ & $\mathbf{+ 0 , 5 0 9}$ & 0,039 & 13,18 & 175,97 & 0,00 & $\mathbf{0 , 8 3}$ & 0,67 \\
\hline a) buildings and grounds & $\mathbf{+ 0 , 4 1 9}$ & 0,039 & 10,85 & 119,65 & 0,00 & $\mathbf{0 , 3 2}$ & 0,18 \\
\hline $\begin{array}{l}\text { b) technical equipment and ma- } \\
\text { chinery }\end{array}$ & $\mathbf{+ 0 , 4 4 2}$ & 0,036 & 12,12 & 148,04 & 0,00 & $\mathbf{0 , 7 5}$ & 0,59 \\
\hline Computer software & $\mathbf{+ 0 , 2 0 9}$ & 0,044 & 4,72 & 35,70 & 0,00 & $\mathbf{0 , 5 9}$ & 0,51 \\
\hline Launching new products & $\mathbf{+ 0 , 5 6 7}$ & 0,038 & 14,97 & 227,43 & 0,00 & $\mathbf{0 , 8 1}$ & 0,63 \\
\hline $\begin{array}{l}\text { Implementation of new technology } \\
\text { processes (including): }\end{array}$ & $\mathbf{+ 0 , 3 8 0}$ & 0,035 & 10,83 & 118,01 & 0,00 & $\mathbf{0 , 5 5}$ & 0,40 \\
\hline a) production methods & $\mathbf{+ 0 , 3 8 3}$ & 0,037 & 10,43 & 109,75 & 0,00 & $\mathbf{0 , 3 9}$ & 0,25 \\
\hline b) non production systems & $\mathbf{+ 0 , 6 5 1}$ & 0,039 & 9,04 & 83,73 & 0,00 & $\mathbf{0 , 2 9}$ & 0,18 \\
\hline c) support systems & $\mathbf{+ 0 , 3 6 9}$ & 0,038 & 9,63 & 93,89 & 0,00 & $\mathbf{0 , 3 1}$ & 0,20 \\
\hline Cooperation with suppliers & $\mathbf{+ 0 , 2 7 0}$ & 0,065 & 4,15 & 17,75 & 0,00 & $\mathbf{0 , 0 5}$ & 0,03 \\
\hline Cooperation with competitors & $\mathbf{+ 0 , 2 3 3}$ & 0,092 & 2,53 & 6,59 & 0,01 & $\mathbf{0 , 0 2}$ & 0,01 \\
\hline $\begin{array}{l}\text { Cooperation with Polish Academy } \\
\text { of Sciences units }\end{array}$ & $\mathbf{+ 0 , 3 4 0}$ & 0,065 & 5,22 & 28,45 & 0,00 & $\mathbf{0 , 0 6}$ & 0,03 \\
\hline Cooperation with universities & $\mathbf{+ 0 , 3 6 1}$ & 0,053 & 6,83 & 48,32 & 0,00 & $\mathbf{0 , 1 1}$ & 0,05 \\
\hline $\begin{array}{l}\text { Cooperation with domestic R\&D } \\
\text { units }\end{array}$ & $\mathbf{+ 0 , 4 3 2}$ & 0,091 & 4,73 & 24,65 & 0,00 & $\mathbf{0 , 0 3}$ & 0,01 \\
\hline $\begin{array}{l}\text { Cooperation with foreign R\&D } \\
\text { units }\end{array}$ & $\mathbf{+ 0 , 2 4 8}$ & 0,040 & 6,25 & 39,48 & 0,00 & $\mathbf{0 , 2 5}$ & 0,18 \\
\hline Cooperation with customers & $\mathbf{+ 0 , 3 8 9}$ & 0,035 & 10,99 & 121,65 & 0,00 & $\mathbf{0 , 5 0}$ & 0,35 \\
\hline Overall innovation cooperation & $\mathbf{+ 0 , 5 7 4}$ & 0,037 & 15,66 & 249,86 & 0,00 & $\mathbf{0 , 4 5}$ & 0,24 \\
\hline p $<0,05$ & & & & & & & \\
\hline & & & & & & \\
\hline
\end{tabular}

Source: own study based on questionnaire research evidence.

In summary, companies in the prosperity period are significantly more likely to implement different forms of innovation activity, mostly in the R\&D work area, investment in new fixed assets, implementation of new products and technological processes in the production systems or the vertical innovation cooperation. However, not all indicated areas should be potentially supported by different mechanisms of the innovation policy. This mostly results from the fact of reaching the probability value much above the average (certainty of events). In this situation, the meaning of the company support should be considered, which regardless of the occurrence of instruments of the innovation policy will implement different forms of the innovation activity (displacing efficiently operating market mechanisms). Thus, the directions of stimulation in the revival period should hover around the following activities: the R\&D activity, investment in new 
buildings, implementation of new products and methods of their production, innovation cooperation along the supply chain. In terms of others, we will deal with 1) the situation of market displacing by the state policy (high probability values), and 2) with non-system attempts to stimulate the innovation activity - high costs and its low effectiveness (low probability values).

As a result of the conducted studies, we can observe that the period of the economic acceleration favours the system of acceleration of the technological progress of the Polish industry and, basically, at this stage of its development it should be supported by instruments of the innovation policy, yet not in every area. Such "intelligent" stimulation should accelerate technological changes in the industry, which in turn will contribute to the system, high and self-sustaining auto-dynamism of innovation in Poland.

\section{Recession and the Innovation Activity of the Industrial Companies}

In the analysed period, 916 industrial companies declared that they were in the recession period $(18,6 \%)$. They constituted a relatively small percentage of the analysed group of entities, and in addition, taking into account the occurrence of mostly positive trends in the economy during the analyses, the obtained information can be considered reliable.

As expected, since the period of prosperity had a positive and system influence on the innovation processes, the time of recession is responsible for the opposite phenomenon (JRC, 2010). This time, in sixteen out of eighteen potential econometric models, the parameters and models as a whole, reached the statistical significance. The lack of important dependencies was observed only for the innovation cooperation with the PAS units and foreign scientific units, which means that the indicated activity does not decrease significantly during downturn. In other cases, all parameters reached the negative sign, and thus the recession period has a system and negative influence on the innovation behaviours of the studied companies. 
Table 3. The parameter value for the independent variable , economic recession”, in the probit models describing the system of industrial innovation in Poland

\begin{tabular}{|c|c|c|c|c|c|c|c|}
\hline Innovation feature & Coef & $\begin{array}{l}\text { Std. } \\
\text { error }\end{array}$ & t-test & $\mathrm{Chi}^{2}$ & $\mathbf{P}>|\mathbf{z}|$ & $p_{1}$ & $\mathbf{p}_{2}$ \\
\hline R\&D expenditure & $-0,503$ & 0,049 & $-10,23$ & 109,12 & 0,00 & $\mathbf{0 , 2 2}$ & 0,39 \\
\hline $\begin{array}{l}\text { Investment in new fixed assets } \\
\text { (including): }\end{array}$ & $-0,472$ & 0,047 & $-10,17$ & 101,92 & 0,00 & $\mathbf{0 , 6 3}$ & 0,79 \\
\hline a) buildings and grounds & $-0,370$ & 0,052 & $-7,09$ & 52,42 & 0,00 & $\mathbf{0 , 1 7}$ & 0,28 \\
\hline $\begin{array}{l}\text { b) technical equipment and ma- } \\
\text { chinery }\end{array}$ & $-0,386$ & 0,045 & $-8,52$ & 72,27 & 0,00 & 0,56 & 0,70 \\
\hline Computer software & $-0,350$ & 0,045 & $-7,79$ & 60,74 & 0,00 & $\mathbf{0 , 5 0}$ & 0,63 \\
\hline Launching new products & $-0,235$ & 0,045 & $-5,26$ & 27,69 & 0,00 & 0,47 & 0,57 \\
\hline $\begin{array}{l}\text { Implementation of new technology } \\
\text { processes (including): }\end{array}$ & $-0,507$ & 0,046 & $-11,06$ & 121,19 & 0,00 & $\mathbf{0 , 5 8}$ & 0,76 \\
\hline a) production methods & $-0,283$ & 0,042 & $-6,68$ & 39,51 & 0,00 & $\mathbf{0 , 3 9}$ & 0,50 \\
\hline b) non production systems & $-0,428$ & 0,050 & $-8,62$ & 77,10 & 0,00 & $\mathbf{0 , 2 1}$ & 0,35 \\
\hline c) support systems & $-0,270$ & 0,052 & $-5,22$ & 28,07 & 0,00 & $\mathbf{0 , 1 8}$ & 0,26 \\
\hline Cooperation with suppliers & $-0,324$ & 0,051 & $-6,31$ & 41,12 & 0,00 & $\mathbf{0 , 1 8}$ & 0,28 \\
\hline Cooperation with competitors & $-0,314$ & 0,095 & $-3,31$ & 12,14 & 0,00 & $\mathbf{0 , 0 2}$ & 0,05 \\
\hline Cooperation with universities & $-0,219$ & 0,088 & $-2,49$ & 6,60 & 0,01 & $\mathbf{0 , 0 3}$ & 0,05 \\
\hline $\begin{array}{l}\text { Cooperation with domestic R\&D } \\
\text { units }\end{array}$ & $-0,280$ & 0,073 & $-3,86$ & 15,87 & 0,00 & $\mathbf{0 , 0 5}$ & 0,09 \\
\hline Cooperation with customers & $-0,156$ & 0,052 & $-3,00$ & 9,15 & 0,00 & $\mathbf{0 , 1 8}$ & 0,22 \\
\hline Overall innovation cooperation & $-0,295$ & 0,046 & $-6,43$ & 41,87 & 0,00 & $\mathbf{0 , 3 4}$ & 0,45 \\
\hline
\end{tabular}

Source: own study based on questionnaire research evidence.

Analysing the achieved probability values, we can observe their strong internal differentiation. However, the ones which take very high values are lacking, as it happened in the revival phase. Despite the economic slowdown period, companies are still intensely interested in financing (apart from ED works and investments in new buildings) and implementation of new products and technologies as in the case of other, more developed countries, which may suggest the cyclic independence of these areas (OECD, 2009; Paunov, 2011, pp. 24-35). Chances for such phenomena are contained in the scope of 47\%-63\%. However, in case of the implementation of new technological processes, their internal structure is highly diversified. Only the implementation of new production methods is characterised by a relatively high probability $(0,39)$, although, at the same time, twice larger than others, which is the new by-production and support systems.

The establishment of innovation cooperation less often takes place in the recession period. Its greatest chances can be observed again in case of vertical links in the supply chain - with suppliers and recipients (over 18\%), 
which still significantly differs from the phenomena of financing and implementation of new solutions. In other cases, probability oscillates around zero.

Summing up, the potential support in the recession phase with the "visible hand" mechanisms (innovation policy) in Poland should apply to a small number of areas. Particularly susceptible to acceleration are the investments in new machines and technical equipment $(00,56)$, purchase of the computer software $(0,50)$, implementation of new products $(0,47)$ and production methods $(0,39)$. The others reach low, or very low probability values, and the attempts to support them will have the characteristics of non-system, isolated and secluded actions without the effect on the industry as a whole. In other words, the acceleration of innovation processes using the instruments of the innovation policy during recession should be performed with great caution and focus of efforts on the narrow group of areas prognosticating the system effect, according to the concept of "intelligent specialisations".

\section{Economic Stagnation and the Innovation Activity of the Industrial Companies}

In $27,3 \%$ of the studied cases it was declared that the companies are in the stagnation phase with unchanged incomes in the analysed period. Since we have encountered the polarizing approach to the implementation of innovation processes in the revival and recession, it was expected that the stagnation phase will become the bridge connecting the mentioned opposite phases of the economy cycle.

However, it did not happen. It turned out that, like in case of the "economic slowdown" variable, there were sixteen estimated models with statistically significant parameters. The only change applied to the innovation cooperation and consisted of the lack of models for the cooperation with competitors, and the appearance of foreign scientific units. However, what is the most important is the fact that in all models the parameters reached the negative values. And thus, the phase of economic stagnation has a system effect on the inhibition of innovation processes in the Polish companies. Moreover, the power of this negative impact, taking into account the achieved probability values, is similar to the one from the recession period, and sometimes it is even higher. 
Table 4. The parameter value for the independent variable ,economic stagnation”, in the probit models describing the system of industrial innovation in Poland

\begin{tabular}{|l|c|c|c|c|c|c|c|}
\hline \multicolumn{1}{|c|}{ Innovation feature } & Coef & $\begin{array}{c}\text { Std. } \\
\text { error }\end{array}$ & t-test & $\mathbf{C h i}^{2}$ & $\mathbf{P}>|\mathbf{z}|$ & $\mathbf{p}_{\mathbf{1}}$ & $\mathbf{p}_{\mathbf{2}}$ \\
\hline R\&D expenditure & $\mathbf{- 0 , 3 6 4}$ & 0,041 & $-8,80$ & 78,96 & 0,00 & $\mathbf{0 , 2 6}$ & 0,39 \\
\hline $\begin{array}{l}\text { Investment in new fixed assets } \\
\text { (including): }\end{array}$ & $\mathbf{- 0 , 2 2 6}$ & 0,042 & $-5,40$ & 29,99 & 0,00 & $\mathbf{0 , 7 0}$ & 0,78 \\
\hline a) buildings and grounds & $\mathbf{- 0 , 2 6 1}$ & 0,044 & $-5,97$ & 36,26 & 0,00 & $\mathbf{0 , 2 0}$ & 0,28 \\
\hline $\begin{array}{l}\text { b) technical equipment and ma- } \\
\text { chinery }\end{array}$ & $\mathbf{- 0 , 2 3 5}$ & 0,040 & $-5,88$ & 34,40 & 0,00 & $\mathbf{0 , 6 1}$ & 0,70 \\
\hline Computer software & $\mathbf{- 0 , 3 5 6}$ & 0,039 & $-9,05$ & 82,09 & 0,00 & $\mathbf{0 , 5 1}$ & 0,64 \\
\hline Launching new products & $\mathbf{- 0 , 0 7 8}$ & 0,039 & $-2,02$ & 4,03 & 0,04 & $\mathbf{0 , 5 3}$ & 0,56 \\
\hline $\begin{array}{l}\text { Implementation of new technology } \\
\text { processes (including): }\end{array}$ & $\mathbf{- 0 , 2 7 2}$ & 0,041 & $-6,65$ & 44,00 & 0,00 & $\mathbf{0 , 6 6}$ & 0,75 \\
\hline a) production methods & $\mathbf{- 0 , 2 6 2}$ & 0,040 & $-6,63$ & 44,61 & 0,00 & $\mathbf{0 , 4 1}$ & 0,51 \\
\hline b) non production systems & $\mathbf{- 0 , 1 7 3}$ & 0,041 & $-4,20$ & 17,77 & 0,00 & $\mathbf{0 , 2 8}$ & 0,34 \\
\hline c) support systems & $\mathbf{- 0 , 2 4 2}$ & 0,044 & $-5,46$ & 30,41 & 0,00 & $\mathbf{0 , 1 9}$ & 0,26 \\
\hline Cooperation with suppliers & $\mathbf{- 0 , 2 3 7}$ & 0,043 & $-5,46$ & 30,33 & 0,00 & $\mathbf{0 , 2 1}$ & 0,28 \\
\hline Cooperation with universities & $\mathbf{- 0 , 2 9 8}$ & 0,078 & $-3,82$ & 15,77 & 0,00 & $\mathbf{0 , 0 3}$ & 0,05 \\
\hline $\begin{array}{l}\text { Cooperation with domestic } \\
\text { R\&D units }\end{array}$ & $\mathbf{- 0 , 2 6 2}$ & 0,061 & $-4,27$ & 19,13 & 0,00 & $\mathbf{0 , 0 6}$ & 0,09 \\
\hline $\begin{array}{l}\text { Cooperation with foreign } \\
\text { R\&D units }\end{array}$ & $\mathbf{- 0 , 4 0 6}$ & 0,115 & $-3,54$ & 14,72 & 0,00 & $\mathbf{0 , 0 1}$ & 0,02 \\
\hline Cooperation with customers & $\mathbf{- 0 , 2 0 4}$ & 0,045 & $-4,50$ & 20,60 & 0,00 & $\mathbf{0 , 1 7}$ & 0,23 \\
\hline Overall innovation cooperation & $\mathbf{- 0 , 2 6 7}$ & 0,040 & $-6,70$ & 45,28 & 0,00 & $\mathbf{0 , 3 5}$ & 0,46 \\
\hline \begin{tabular}{l} 
p<0,05 \\
\hline
\end{tabular} & & & & & & \\
\hline
\end{tabular}

Source: own study based on questionnaire research evidence.

The potential directions of support of the innovation activity should apply to investments in new machines and technical equipment $(0,61)$, purchase of computer software $(0,51)$, implementation of new products $(0,53)$ and methods of their production $(0,41)$. Chances for the innovation cooperation reach very low values and are once again the domain of relationships along the supply chain. This does not change the fact that they do not have chances for a system innovation dynamism of the industry while undertaking the attempts to stimulate them.

In conclusion, the stagnation phase has a system and negative influence on the implementation of the innovation processes in the Polish industry, like in the recession period. Thus, companies are more often interested in the limitation of the risk connected with this activity than the attempt to anticipate the market events. Entrepreneurs themselves adopt the expectant and conservative position. This is all the more disturbing that the strongest fluctuations apply to areas, which by definition should be long-term in na- 
ture (independent on the business cycle), like the R\&D activity or innovation cooperation. This reflects mainly the acute treatment of these functions and the lack of noticing of their strategic potential (Marceau, 2002, pp. 209221). Taking into account the fact that the Polish economy is slowly coming out of the stagnation phase, in the near future we should not expect the high innovation dynamism. This does not change the fact that there are areas of potential support directions of the discussed activity, despite the adverse market conditions.

\section{Conclusions}

After analyzing the relationships taking place between the economic prosperity and activity in the sphere of innovation activity in the national industrial system, it can be observed that this phenomenon is mostly cyclical and is shaped like in other countries. During the period of revival, the increase of interest in financing and implementing new technologies can be observed, while during recession and the economic stagnation, the entities resign from conducting the innovation activity. Therefore, at this stage the hypothesis of Gerhard Mensch about the innovation acceleration in the economic downturn cannot be positively verified. Such a phenomenon, of course, has both advantages and limitations, because from one perspective, the cycle changes influence the market verification of the risky ventures. While on the other, the innovation activity has a long-term significance and dimension, and thus, the high volatility may disrupt the natural rhythm of creating new solutions, or their transfer and implementation.

Basing on the conducted studies, it can be stated that the business factor systemically illustrates the innovation behaviours of the industry in Poland, what is evidenced by the number of statistically significant estimated profit models. Although all areas of the discussed activity have been described, we can observe significant differences within the achieved probability values. High chances of the phenomena are usually noted for the areas of financing (outside the R\&D sphere) and implementation of new technological solutions, when the innovation cooperation in Poland is very rare, especially with the institutional $R \& D$ sphere. This demonstrates the low maturity of the national industrial system in the possibility of the broad entering into horizontal innovation interactions. Thus, this area in principle should not be temporarily supported by mechanisms of the innovation policy, both on the national and regional level, until it can independently systemically accelerate the innovation processes. Otherwise, the attempts to stimulate this type of relationships will be incidental, isolated and secluded in nature, 
without affecting the system as a whole. After analysing the existing main directions of the country's influence on the innovation activity in our country, it should be stated that, unfortunately, we are dealing with such mechanisms, and they constitute the core of the Polish innovation policies implemented on the national and regional levels. System changes according to the evolutionary time perspective, however, require time, so that it can be able to initiate the natural and adequate immanent systemic autodynamism, and consequently, obtain the base ability to accelerate innovation processes, which in turn will subject itself to the successful stimulation with mechanisms of the state policy.

The use of the probit type of modelling has in an interesting way illustrated the shape, as well as innovation mechanisms found in the national industrial system. According to the author, it can constitute an interesting alternative for the studies of the dynamics of phenomena. In terms of statistics, so far they have not reached satisfactory time series, and what goes with it, they do not allow for the calculations and the appropriate inference. Therefore, it is an attempt of the systemic understanding of the discussed economic phenomena.

Taking into consideration the achieved study results, the support of innovation activity in Poland should be differentiated depending on the phase of the business cycle. Such a mechanism should contribute to a significantly more favourable influence of the state policy and its individual support instruments on the system and research and developmental innovation activity of industrial companies.

\section{References}

Aghion, P., Saint-Paul, G. (1998). Uncovering some causal relationships between productivity growth and the structure of economic fluctuations: A tentative survey. Labour, 12(2).

Archibugi, D., Filippetti, A., \& Frenz, M. (2013). The impact of the economic crisis on innovation: Evidence from Europe. Technological Forecasting \& Social Change, 80(7), http://dx.doi.org/10.1016/j.techfore.2013.05.005.

Barrett, C. W., Musso, C. S., \& Padhi, A. (2009). Upgrading R\&D in a downturn. The McKinsey Quarterly, 2.

Canton, E., \& Uhlig, H. (1999). Growth and the cycle: Creative destruction versus entrenchment. Journal of Economics, 69(3), http://dx.doi.org/10.1007/ BF01231161.

Clark, J., Freeman, C., \& Soete, L. (1981). Long waves, inventions, and innovations. Futures, 13(4). 
D’Estea, P., Iammarinob, S., Savonac, M., \& von Tunzelmann, N. (2012). What hampers innovation? Revealed barriers versus deterring barriers. Research Policy, 41(2).

Dominiak, J., \& Churski, P. (2012). Rola innowacji w kształtowaniu regionów wzrostu i stagnacji gospodarczej w Polsce. Studia Regionalne i Lokalne, 4.

Etzkowitz, H., \& Leydesdorff, L. (2000). The dynamics of innovation: from National Systems and "Mode 2" to a Triple Helix of university-industrygovernment relations. Research Policy, 29.

Francois, P., \& Lloyd-Ellis, H. (2003). Animal Spirits through Creative Destruction, American Economic Review, 93(3), http://dx.doi.org/10.1257/000282 803322156972

GUS (2012). Działalność innowacyjna przedsiębiorstw w latach 2009-2011. Informacje i opracowania statystyczne, Warszawa.

Jasiński, A. H. (2014). Innowacyjność w gospodarce Polski. Modele, bariery, instrumenty wsparcia. Warszawa: Wyd. Uniwersytetu Warszawskiego.

Cincera, M., Cozza, C., Tübke, A., \& Voigt, P. (2010). Doing R\&D or not, that is the question (in a crisis...). JRC: IPTS working paper on corporate $R \& D$ and innovation, 12.

KE (2013). Innovation Union Scoreboard 2013 from http://ec.europa.eu (26.09.2013).

Madrid-Guijarro, A., García-Pérez-de-Lema, D., \& Van Auken, H. (2013). An Investigation of Spanish SME Innovation during Different Economic Conditions. Journal of Small Business Management, 51(4), http://dx.doi.org/10. $1111 / \mathrm{jsbm} .12004$.

Malerba, F., \& Orsenigo, L. (1995). Schumpeterian Patterns of Innovation. Cambridge Journal of Economics, 19.

Marceau, J. (2002). Divining directions for development: a co-operative industrygovernment-public sector research approach to establishing $R \& D$ priorities. $R \& D$ Management, 32.

OECD (2005). Podręcznik Oslo. Zasady gromadzenia i interpretacji danych dotyczacych innowacji. Wydanie trzecie. Paryż.

OECD (2009). Policy Responses to the Economic Crisis: investing in Innovation for Long-Term Growth. Paris.

Paunov, C. (2011). The global crisis and firms' investments in innovation. Research Policy, 41.

Pavitt, K. (1999), The Nature of Technology. In K. Pavitt (Ed), Technology, Management and Systems of Innovation. Cheltenham: Edward Elgar.

Schumpeter, J. (1939). Business Cycle. A Theoretical, Historical and Statistical Analysis of the Capitalist Process. New York Toronto London: McGraw-Hill Book Company.

Shleiffer, A. (1986). Implementation Cycles. The Journal of Political Economy, 94(6). http://dx.doi.org/10.1086/261428.

Soete, L. (2009). Challenges for making European research an engine of competitiveness. Presented at VINNOVA workshop: How can a future ERA support 
92 Arkadiusz Świadek

and stimulate research, innovation, and sustainable economic growth in Europe? Berlin, March 17th,

Stanisz, A. (2007). Przystępny kurs statystki. Tom 2. Kraków: Statsoft.

Stiglitz, J. (1993). Endogenous Growth and Cycles, NBER WP Nº4286,. 